\title{
Synthesis and antioxidant evaluation for monocarbonyl curcuminoids and their derivatives
}

Autor:

Agel, K N (1)

Abood, $E^{(2)}$

Alsalim, $\mathbf{T}^{(3)}$

\section{ARTÍCULO DE INVESTIGACIÓN CIENTÍFICA Y TECNOLÓGICA}

How to cite this paper:

Agel, K N, Abood, E, Alsalim, T., Synthesis and antioxidant evaluation for monocarbonyl curcuminoids and their derivatives, Basrah, Iraq. Innovaciencia Facultad de Ciencias Exactas, Naturales y Agropecuarias. 2018; 6(1) S1: 1-13.

Reception date:

Received: 15 August 2018

Accepted: 25 November 2018

Published Online: 28 December 2018

DOI:

http://dx.doi.org/10.15649/2346075X.481

Keywords:

Cucumine; Monocarbonylcurcuminoids; Antioxidant; DPPH; Pepronal; 4-thiomethoxy benzaldehyde

\section{ABSTRACT}

Introduction: Curcumin is a yellow pigment extracted from the Curcuma longa L, which have a several biological activities and pharmacological properties. Curcuminoids have a wide range as antioxidant not only in a food system, but also for biological systems. Materials and Methods: Acetone, 4-thiomethoxy benzaldehy, pepronal, thiosemicarbazide, 4-phenylthiosemicarbazide and chloroethylacetate. The two Analogous of monocarbonyl curcuminoids (MCCs) have been synthesized by claisen -Schmidt condensation from the reaction between one mole of acetone with two moles of appropriate aromatic aldehydes (4-thiomethoxy benzaldehyde and pepronal) then synthesized their hetero derivatives. The pyrazols derived from the reaction MCCs with hydrazine or one of their derivative (thiosemicarbazide, 4-phenylhydrazine).Results and Discussion:All synthesized compounds were characterized by various spectroscopic techniques such as FTIR, ${ }^{1} \mathrm{HNMR},{ }^{13} \mathrm{CNMR}$, Mass spectroscopies and CHN analysis. The antioxidant activity of synthesized MCCs, 1, 2, 1a, 2a, 3, were determined by the ability to scavenge the stable 1,1-diphenyl-2-picryl hydrazyl (DPPH) free radical according to Blois method. The DPPH inhibition activity was measured by spectrophometric method. The polyhydroxy curcuminoid has showed a high activity for scavenging of DPPH radicals, the reason is the hydroxyl phenolic group $\mathrm{OH}$ give the compound high activity of scavenging the radical by donating hydrogen atom to the DPPH radicals and inhibition the radical activity by hydrogen atom transfer (HAT). Therefore the scavenge of radical activitywill be in the order: $3>2 \mathrm{a}>1 \mathrm{a}>2>1$ and the half maximal inhibitory concentration $\left(\mathrm{IC}_{50}\right)$ between (17.35-135.2) $\mathrm{mmol} / \mathrm{L}$.Conclusions: The proposed structure of the synthesized compounds were confirmed by used a spectroscopic technique such as, FTIR, Mass spectra (EI), ${ }^{1} \mathrm{H}$ and ${ }^{13} \mathrm{C}$ NMR, The antioxidant activity of curcuminoids were studied by using DPPH as a source of radicals. The higher activity of compounds can be attributed to present the phenolic $\mathrm{OH}$ group.

\footnotetext{
(1) Chemistry Department, College of Education for Pure Sciences, University of Basrah, Basrah-16001, Iraq, kadhim.ali46@yahoo.com

2) Polymer Research Center, University of Basrah, Basrah-16001, Iraq,einasalnasir@yahoo.com

3) Chemistry Department, College of Education for Pure Sciences, University of Basrah, Basrah-16001, Iraq, tahseenalsalim@uobasrah.edu.iq
} 


\section{INTRODUCTION}

Curcumine is a natural extract from rhizome of curcumine longa (Turmeric) ${ }^{(1)}$ The pigment yellow color of extracted contained three isomers of curcuminoids (curcumine, demethoxy curcumine and bis demethoxy curcumine $)^{(2)}$. This natural compound has been used as food pigment and in food industries ${ }^{(3)}$.

\section{Figure 1 Some examples of Curcumins}<smiles>COc1cc(/C=C/C(=O)CC(=O)/C=C/c2ccc(O)cc2)ccc1O</smiles><smiles>COc1cc(/C=C/C(=O)CC(=O)/C=C/c2ccc(O)c(OC)c2)ccc1O</smiles>

In the last decades the pharmacological activity of curcumine has many applications in-vivo and -vitro as antioxidant $t^{(4)}$, anticancer ${ }^{(5)}$, antifungalanti ${ }^{(0)}$, inflammator ${ }^{(7)}$, antibacterial ${ }^{(8)}$, and antiviral ${ }^{(9)}$. Because of the curcumine poor solubility in aqueous media $\frac{(10)}{}$, which is the most cumin problems of this material leads to poor bioavailability and absorption then cause a rapid metabolism. Therefore, this material attracted a lot of attention in past decades, especially by modifying their structure and preparing new analogues to increase their bioactivity as anticancer and antioxidant ${ }^{(11)}$. In this study, two monocarbonyl curcumine analogous (MCCs) and their derivatives have been designed, and their activity as an antioxidant agents for scavenging of DPPH radicals have been nvestigated.

\section{MATERIALS AND METHOD}

\section{Materials and Reagents}

All the chemicals and solvents were used with analytical grade (AR) and highestpurity which included pepronal and thiomethoxybenzaldehyde (Aldrich), thiosemicarbazide, pyrogallol and chloroacetylchloride (Merck). All the solvents were used equipped by (BDH) company.

\section{Instrumentation}

FTIR spectra of all compounds were recordedon shimadzu FTIR model Affinity spectrophotometer using $\mathrm{KBr}$ pellets in the range $(4000-400) \mathrm{cm}^{-1}$. The Mass spectra were scanned by the EI technique $70 \mathrm{eV}$ with an Agilent Technologies 5975 spectrometer. The experimental values of ${ }^{1} \mathrm{H}$ and ${ }^{13} \mathrm{CNMR}$ spectra for the studied compounds were scanned on a 
Bruker $400 \mathrm{MHz}$ spectrometer with a field gradient to operateat $400 \mathrm{MHz}$ for proton observation and $100 \mathrm{MHz}$ for carbon observation using DMSO- $\mathrm{d}_{6}$ as solvent and TMS as internal standard. Elemental analysis (CHNS)weremeasured by using elementar Vario MICRO. UV-VISIBLEspectra were measured using a PG-instrument $\mathrm{T} 80^{+}$spectrophotometer.

\section{Synthesis}

Preparation of monocarbonyl curcumicoids (MCCs) (1, and 2):

The monocarbonyl curcuminoids 1 , and 2 were synthesized by Claisen-Schmidt condensation between acetone $(16.65 \mathrm{mmol})$ with appropriate aromatic aldehydes $(33.7 \mathrm{mmol})$ in $(50 \mathrm{~mL})$ etanol, and (34 mmol) of sodium hydroxide solution as a catalyst. The reaction mixture wasstirred for further 10hours at room temperature. The solid product was collected by filtration, and then waswashed by water several times, dried then recrystallized from the appropriate solvent (scheme 1).

\section{(1E,4E)-1,5-bis(benzo[d] [1,3] dioxol-5-yl) penta-}

\section{1,4-dien-3-one (1):}

Color: yellow powder, recrystallized from ethyl acetate, yield: $84 \%$, M.P.: $186-188^{\circ} \mathrm{C},{ }^{1} \mathrm{HNMR}$ (400 $\left.\mathrm{MHz}, \mathrm{DMSO}-\mathrm{d}_{6}, \delta \mathrm{ppm}\right): 6.1\left(\mathrm{~s}, 4 \mathrm{H},-\mathrm{OCH}_{2} \mathrm{O}-\right), 7.00$ $(\mathrm{d}, 2 \mathrm{H}, J=5 \mathrm{~Hz}, \mathrm{CH}=\mathrm{C}), 7.19(\mathrm{~d}, 2 \mathrm{H}, J=5 \mathrm{~Hz}$, aromatic),7.26 (d, $2 \mathrm{H}, J=10 \mathrm{~Hz}$, aromatic),7.45(s, $2 \mathrm{H}$, aromatic),7.71(d, $2 \mathrm{H}, J=5 \mathrm{~Hz}, \mathrm{CH}=\mathrm{C}) .{ }^{13} \mathrm{CNMR}$ (100MHz, DMSO-d, $\delta$ ppm): 102.1, 107, 109, 124.3, $125.7,129.7,142.8,148.2,149.8,189.1$. MS (70 eV, $\mathrm{m} / \mathrm{z}$ ): 322[M], 279, 189, 175, 135. FTIR (KBr disk, v, $\left.\mathrm{cm}^{-1}\right):$ 3014, 2912, 1643, 1598, 1490, 1190, 1118. Anal. calc. for $\mathrm{C}_{19} \mathrm{H}_{14} \mathrm{O}_{5}$ : C, 70.80; H, 4.38; found: C, 69.47; H, 4.24.

\section{(1E,4E)-1,5-bis(4-(methylthio) phenyl) penta- 1,4-dien-3-one (2): \\ Color: yellow powder, recrystallized from ethanol,}

yield: $80 \%$, M.P.: $158-159^{\circ} \mathrm{C},{ }^{1} \mathrm{H}$ NMR $(400 \mathrm{MHz}$, DMSO-d,$\delta \mathrm{ppm}): 2.52\left(\mathrm{~s}, 6 \mathrm{H},-\mathrm{SCH}_{3}\right), 7.33$ (d, $2 \mathrm{H}, J=5 \mathrm{~Hz}, \mathrm{CH}=\mathrm{C}), 7.27(\mathrm{~d}, 4 \mathrm{H}, J=10 \mathrm{~Hz}$, aromatic), $7.72(\mathrm{~d}, 4 \mathrm{H}, J=10 \mathrm{~Hz}$, aromatic), $7.75(\mathrm{~d}, 2 \mathrm{H}, J=$ $5 \mathrm{~Hz}, \mathrm{CH}=\mathrm{C}) .{ }^{13} \mathrm{CNMR}\left(100 \mathrm{MHz}, \mathrm{DMSO}_{6}, \delta\right.$ ppm):14.7, 125.3, 126.1, 129.4, 131.6, 142.2, 142.5, 186.6. MS (70 eV, m/z): 226.2[M], 311.2, 279.1, 204.2, 177.1, 134.1, 102.1, 89.1, 77.1, 48.1. FTIR $\left(\mathrm{KBr}\right.$ disk, v, $\left.\mathrm{cm}^{-1}\right)$ : 3016, 2919, 1643, 1589, 1489, 1337. Anal. calc. for $\mathrm{C}_{19} \mathrm{H}_{18} \mathrm{OS}_{2}$ : C, 69.90; H, 5.56; S, 19.64, found: C, 68.59; H, 5.48; S, 19.47.

General procedure for the synthesis pyrazols(1a-c) \&(2a-b)

MACs $(3.11 \mathrm{mmol})$ dissolved in $(50 \mathrm{~mL})$ of etanol, and $(3.13 \mathrm{mmol})$ of appropriate hydrazine was added or one of their derivatives (hydrazine monohydrate, thiosemicarbazide, and 4-phenyl hydrazine), then (0.6 g) sodium hydroxide was added to the mixture. The reaction mixture was heated under reflux for 16 hours, then cooled down and poured into iced water, then neutralized by the addition $0.1 \mathrm{~N} \mathrm{HCl}$. The product was collectedby filtration, and then dried and recrystalized from a suitable solvent (scheme 2).

\section{(E)-5-(benzo[d] [1,3] dioxol-5-yl)-3-(2-(benzo[d]} [1,3]dioxol-5-yl) vinyl)-4,5-dihydro-1H-pyrazole-1-carbothioamide (1a):

Color: yellow powder, recrystallized from benzene: petroleum ether,yield:55.9\%, M.P: 208-210 ${ }^{\circ} \mathrm{C}$, ${ }^{1} \mathrm{HNMR}\left(400 \mathrm{MHz}, \mathrm{DMSO}-\mathrm{d}_{6}, \delta\right.$ ppm):2.97(dd, H, $J=5 \mathrm{~Hz}, \mathrm{CH}_{2}-\mathrm{C}$ pyrazole ring), $3.68(\mathrm{dd}, \mathrm{H}, J=10 \mathrm{~Hz}$, $\mathrm{CH}_{2}-\mathrm{C}$ pyrazole ring), 5.81 (dd , $\mathrm{H}, J=5 \mathrm{~Hz}, \mathrm{CH}-\mathrm{N}$ pyrazole ring), 5.97 (s, 2H, $\left.-\mathrm{OCH}_{2} \mathrm{O}-\right), 6.05(\mathrm{~s}, 2 \mathrm{H}$, $\left.-\mathrm{OCH}_{2} \mathrm{O}-\right), 6.58(\mathrm{~d}, 1 \mathrm{H}, \mathrm{J}=10 \mathrm{~Hz}, \mathrm{CH}=\mathrm{C}), 6.62(\mathrm{~s}, 1 \mathrm{H}$, Ar) $, 7.04(\mathrm{~d}, 1 \mathrm{H}, J=5 \mathrm{~Hz}, \mathrm{CH}=\mathrm{H}), 6.83-7.28(\mathrm{~d}, 4 \mathrm{H}$, $J=10 \mathrm{~Hz}$, aromatic), $7.48(\mathrm{~s}, 1 \mathrm{H}$, aromatic), $8(\mathrm{~s}, 2 \mathrm{H}$, $\left.\mathrm{NH}_{2}\right) \cdot{ }^{13} \mathrm{CNMR}\left(100 \mathrm{MHz}, \mathrm{DMSO}-\mathrm{d}_{6}, \delta \mathrm{ppm}\right): 41.9$, 62.7, 101.3,101.8, 106.2, 108.7, 108.9, 116.4, 118.7, $123.7,130.5,137.8,139.2,146.5,147.7,148.4,148.7,15$ 7,176,187.6.MS (70 eV, m/z): 395[M], 153, 125, 79, 51. FTIR (KBrdisk, v, $\mathrm{cm}^{-1}$ ), 3458, 3336, 3066, 2891, 
1625, 1583, 1489, 1359, 1253, 1193,1039. Anal. calc. for $\mathrm{C}_{20} \mathrm{H}_{17} \mathrm{~N}_{3} \mathrm{O}_{4} \mathrm{~S}: \mathrm{C}, 60.75 ; \mathrm{H}, 4.33 ; \mathrm{N}, 10.63 ; \mathrm{S}, 8.11$, found: C, 60.14; H, 4.08; N, 10.21; S, 7.88.

(E)-5-(benzo [d] [1,3] dioxo1-5-yl)-3-(2-(benzo[d] [1,3] dioxol-5-yl) vinyl)-N-phenyl-4,5-dihydro-1H-pyrazole-1-carbothioamide (1b):

Color: yellow powder, recrystallized from benzene: petroleum ether, yield:49\%, M.P.: $198-200^{\circ} \mathrm{C}$, ${ }^{1} \mathrm{HNMR}\left(400 \mathrm{MHz}, \mathrm{DMSO}-\mathrm{d}_{6}, \delta \mathrm{ppm}\right): 3.00$ (dd, H, $J=15 \mathrm{~Hz}, \mathrm{CH}_{2}$-Cpyrazole ring), 3.68 (dd, $\mathrm{H}, J=10 \mathrm{~Hz}$, $\mathrm{CH}_{2}-\mathrm{C}$ pyrazole ring), $5.43(\mathrm{dd}, \mathrm{H}, \mathrm{J}=10 \mathrm{~Hz}, \mathrm{CH}-\mathrm{N}$ pyrazole ring), 5.98 and 6.06 (s,4H,- $\left.\mathrm{OCH}_{2} \mathrm{O}-\right), 6.71$ $(\mathrm{d}, 1 \mathrm{H}, J=10 \mathrm{~Hz}, \mathrm{CH}=\mathrm{C}), 6.74-7.36(\mathrm{~m}, 11 \mathrm{H}$,aromatic), $7.58(\mathrm{~d}, 1 \mathrm{H}, J=8 \mathrm{~Hz}, \mathrm{CH}=\mathrm{C}), 8.93(\mathrm{~s}, 1 \mathrm{H}$, $\mathrm{N}-\mathrm{H}),{ }^{13} \mathrm{CNMR}\left(100 \mathrm{MHz}, \mathrm{DMSO}-\mathrm{d}_{6}, \delta\right.$ ppm):41.7, 59.9,106.4, 108.7, 109, 110, 118.6, 119.1, 120.5, 128.7, 128.9, 130.8, 139.7, 146.7, 147.9, 148.4, 151.4, 153.8. FTIR (KBrdisk, v, $\mathrm{cm}^{-1}$ ) 3383, 3037, 2893, 1685, 1654, 1595, 1489, 1244, 1122,1039. Anal. calc. for $\mathrm{C}_{26} \mathrm{H}_{21} \mathrm{~N}_{3} \mathrm{O}_{4} \mathrm{~S}$ : C, 66.23; H, 4.49; N, 8.91; S, 6.80, found: C, 65.82; H, 4.31; N, 7.82; S, 6.44.

(E)-5-(benzo[d] [1,3] dioxol-5-yl)-3-(2-(benzo[d] $[1,3]$ dioxol-5-yl) vinyl)-4,5-dihydro-1H-pyrazole (1c):

Color: yellow powder, recrystallized from methanol,yield: $50 \%$, M.P.: $208-210^{\circ} \mathrm{C},{ }^{1} \mathrm{HNMR}(400 \mathrm{MHz}$, DMSO-d,$\delta$ ppm ): 3.65 (dd, $\mathrm{H}, \mathrm{CH}_{2}-\mathrm{C}$ pyrazole ring), 4.1 (dd, $\mathrm{H}, \mathrm{CH}_{2}-\mathrm{C}$ pyrazole ring), $5.05 \mathrm{ppm}$ (dd, $\mathrm{H}, \mathrm{CH}-\mathrm{N}$ pyrazole ring), 5.96(s, 2H,-OCH $\mathrm{O}_{2}$-), 6.08 (s, 2H,-OCH $\mathrm{O}_{2}$ ), 6.7 (s, H,-NH), 6.81 (d, 1H, $\mathrm{CH}=\mathrm{C}), 6.85-7.37$ (m , 6H, aromatic), $7.43(\mathrm{~d}, 1 \mathrm{H}$, $J=5 \mathrm{~Hz}, \mathrm{CH}=\mathrm{C})$. MS (70 eV, m/z): 336.3[M], 309, 135, 123, 71. FTIR (KBr disk, v, $\mathrm{cm}^{-1}$ ), 3116, 2924, $1627,1604,1489,1242,1111,1033$. Anal. calc. for $\mathrm{C}_{19} \mathrm{H}_{14} \mathrm{~N}_{2} \mathrm{O}_{4}: \mathrm{C}, 68.26 ; \mathrm{H}, 4.22 ; \mathrm{N}, 8.38$, found: C, 67.85; H, 4.24; N, 8.09.
(E)-5-(4-(methylthio) phenyl)-3-(4-(methylthio) styryl)-4,5-dihydro-1H-pyrazole-1-carbothioamide (2a):

Color: yellow powder, recrystallized from ethanol, yield: $53.3 \%$, M.P.: $138-140^{\circ} \mathrm{C},{ }^{1} \mathrm{HNMR}(400 \mathrm{MHz}$, DMSO-d,,$\delta$ ppm):2.44 (s,3H, - $\left.\mathrm{SCH}_{3}\right), 2.49$ (s,3H, $\mathrm{SCH}_{3}$ ), 2.98 (dd, $\mathrm{H},=15 \mathrm{~Hz}, \mathrm{CH}_{2}-\mathrm{C}$ pyrazole ring), 3.7 (dd, $\mathrm{H}, \mathrm{J}=10 \mathrm{~Hz}, \mathrm{CH}_{2}-\mathrm{C}$ pyrazole ring), 5.85 (dd, $\mathrm{H}, J=5 \mathrm{~Hz}, \mathrm{CH}-\mathrm{Npyrazole}$ ring), 7.04-8.08(m, $10 \mathrm{H}$, aromatic \& $\mathrm{CH}=\mathrm{C}), 8.4\left(\mathrm{~s}, 2 \mathrm{H}, \mathrm{NH}_{2}\right)$, MS $(70 \mathrm{eV}$, m/z): 499.3[M], 339, 352, 276, 248, 191, 150, 60. FTIR( $\mathrm{KBr}$ disk , v, $\mathrm{cm}^{-1}$ ), 3417, 3248, 3039, 2916, 1620, 1589, 1489, 1342, 1265,1188,1087. Anal. calc. for $\mathrm{C}_{19} \mathrm{H}_{20} \mathrm{~N}_{2} \mathrm{~S}_{2}$ : C, 67.02; H, 5.92; N, 8.23; S, 18.83, found: C, 66.83; H, 5.88; N, 8.01; S, 17.90 .

(E)-5-(4-(methylthio) phenyl)-3-(4-(methylthio) styryl)-4,5-dihydro-1H-pyrazole (2b):

Color: yellow powder, recrystallized from ethanol: n-hexane, yield: $50.4 \%$, M.P.: $169-171{ }^{\circ} \mathrm{C},{ }^{1} \mathrm{HNMR}$ (400 MHz, DMSO-d,$\delta$ ppm): 2.44 (s,3H,-SCH${ }_{3}$ ), 2.49 (s,3H,-SCH$\left.)_{3}\right), 2.9$ (dd, H, J=5Hz, $\mathrm{CH}_{2}-\mathrm{C}$ pyrazole ring), 3.8 (dd, $\mathrm{H}, \mathrm{CH}_{2}-\mathrm{C}$ pyrazole ring), 5.2 (dd, H, CH-N pyrazole ring), 6.47 (s, H , NH), 7.17$7.56(\mathrm{~m}, 10 \mathrm{H}$, aromatic \& $\mathrm{CH}=\mathrm{C}) . \mathrm{MS}(70 \mathrm{eV}$, m/z): 340.2[M], 307, 277, 137, 103, 91, 78. FTIR (KBr disk, v, $\left.\mathrm{cm}^{-1}\right): 3224,3016,1581,1481,1489$, 1388,1157,1065. Anal. calc. $\mathrm{C}_{20} \mathrm{H}_{21} \mathrm{~N}_{3} \mathrm{~S}_{3}$ : C, 60.12; H, 5.30; N, 10.52; S, 24.07, found: C, 59.79; H, 5.11; N, 10.26; S, 23.87.

Procedure for the synthesis of 2 - chloro -1(2,3,4-trihydroxyphenyl) ethan-1- one:

To a cooled solution of stirred of aluminum chloride $(24 \mathrm{~g})$ dissolved in $\mathrm{DCM}$ at $10-15^{\circ} \mathrm{C},(8 \mathrm{~g})$ of pyrogallol in $(50 \mathrm{~mL})$ DCM was added drop-wisely within 20 $\min$. (5mL) of chloroacetyl chloride was added to the reaction mixture which is still at the same temperature. The temperature of reaction mixture raised up to room temperature and further stirring for 
another 20 hours. After that time the reaction was poured onto $(100 \mathrm{~mL})$ of dilute hydrochloric acid with stirring for 2 hours at room temperature. The solid material wascollectedby filtration and washed with water, then the solid suspended in dilute acetic acid solution and heated to $85^{\circ} \mathrm{C}$. The mixture wascooled down to room temperature. Theproduct was filtered, washed with water and dried, thenrecrystallized from benzene (scheme 3 ).

Color: whitepowder, recrystallized from benzene, white powder, recrystallized from benzene, yield: 85\%, M.P.: $169-170{ }^{\circ} \mathrm{C},{ }^{1} \mathrm{HNMR}(400 \mathrm{MHz}$, DMSO-d,$\delta$ ppm ): 5.03(s,2H,- $\left.\mathrm{CH}_{2}-\right), 6.44(\mathrm{~d}, \mathrm{H}, J=5 \mathrm{~Hz}$, aromatic), $7.3(\mathrm{~d}, \mathrm{H}, \mathrm{J}=5 \mathrm{~Hz}$, aromatic), 8.77, 10.28, 11.63 (s,3H,-OH), ${ }^{13} \mathrm{CNMR}$ ( 100MHz, DMSO-d,$\delta$ ppm): 47.3, 109, 112, 123, 133, 152.2, 153.4, 195.2. MS (70 eV, m/z): 202.1[M], 153,125,79,51. FTIR (KBrdisk, v , cm-1 ${ }^{1}$, 3498, 3390, 3095, 2989,1637, 1523.

Procedure for the synthesis of (E)-4-(2-(5-(benzo[d][1,3]dioxol-5-yl)-3-(2 (benzo[d] [1,3]dioxol-5-yl) vinyl)-4,5-dihydro-1H-pyrazol-1-yl) thiazol-4-yl) benzene-1,2,3-triol (3):

In the reaction vessel $(0.9 \mathrm{~g}, 2.36 \mathrm{mmol})$ of compound (1a), and $(0.48 \mathrm{~g}, 2.36 \mathrm{mmol})$ of compound 2-chloro-1-(2,3,4-trihydroxyphenyl) ethan-1-one dissolved in $(20 \mathrm{~mL})$ of dimethyl formamide. The reaction mixture was heated under reflux for 6 hours. The solid product was collected by filtration, dried then recrystallized from ethylacetate (scheme 4).
Color: light brown powder, recrystallized from ethanol, yield: 56\%, M.P.:260-261 ${ }^{\circ} \mathrm{C},{ }^{1} \mathrm{HNMR}(400 \mathrm{MHz}$, DMSO-d,$\delta$ ppm): 3.12(dd, H, $J=10 \mathrm{~Hz}$, pyrazole ring), 3.84(dd, $\mathrm{H}, J=10 \mathrm{~Hz}$, pyrazole ring), 5.58 (dd, $\mathrm{H}, J=5 \mathrm{~Hz}$, pyrazole ring $), 5.98$, and $6.05(\mathrm{~s}, 4 \mathrm{H}$, $\left.-\mathrm{OCH}_{2} \mathrm{O}-\right), 6.28(\mathrm{~d}, 1 \mathrm{H}, \mathrm{J}=10 \mathrm{~Hz}, \mathrm{CH}=\mathrm{C}), 6.93(\mathrm{~s}, 1 \mathrm{H}$, $\mathrm{H}$ of thiazole), 6.79-7.17 ( $\mathrm{m}, 8 \mathrm{H}$, aromatic), 7.38(d, $1 \mathrm{H}, J=5 \mathrm{~Hz}, \mathrm{CH}=\mathrm{C}) 8.06(\mathrm{~s}, \mathrm{H},-\mathrm{OH}), 8.98(\mathrm{~s}, 1 \mathrm{H},-$ $\mathrm{OH}), 10.64$ (s, H,-OH). ${ }^{13} \mathrm{CNMR}(100 \mathrm{MHz}, \quad \mathrm{DM}-$ SO-d,$\delta$ ppm): 43.1, 64, 101.7, 106.2, 106.3, 107.7, 108.9, 109, 111.1, 116.9 118.4, 119.7, 123.6, 130.9, 133.3, 135.6, 137.5, 145.5, 146.6, 147.2, 148.2, 148.4, 148.5, 149.5, 155.5, 164.MS (70 eV, m/z):543.3[M], 394, 336, 147, 89, 43. FTIR (KBr disk, v, $\mathrm{cm}^{-}{ }^{1}$ ), 3537 , 3429, 3032, 2908,1604, 1489, 1242, 1087, 1037. Anal. calc. $\mathrm{C}_{28} \mathrm{H}_{21} \mathrm{~N}_{3} \mathrm{O}_{7} \mathrm{~S}$ : C, 61.87; H, 3.89; N, 7.73; S, 5.90, found: C, 61.61; H, 3.67; N, 7.57; S, 5.73.

\section{DPPH Radical Scavenging Assay}

The antioxidant activity of synthesized curcuminoids (1, 1a, 2, 2a, and 3) were determined by measuring the ability ofscavenging thestable 2,2-diphenyl-1-picrylhydrazyl(DPPH) free radicals according to Blois method ${ }^{(12,13)}$. The DPPH inhibition activity was measured by spectrophometric method, by mixing $(1 \mathrm{~mL}, 200 \mu \mathrm{mol} / \mathrm{L})$ of ethanolic solution of DPPH with $(1 \mathrm{~mL})$ of different concentrations $(50,100$, and 200$) \mu \mathrm{mol} / \mathrm{L}$ of ethanolic solution of synthesized curcuminoids. The absorbance was read at $517 \mathrm{~nm}$ as functional of differenttimes byusing uv-visble spectrophotometer. Inaddition, there was a notable change DPPH color graduate from violet to yellow or colorless. The percentage of inhibition was calculated by the following equation $\frac{(14,15)}{}$.

$$
\text { \%inhibition percentage }=\frac{A c A s}{A c} \times 100
$$

Ac: control absorbance, the absorbance of pure DPPH

As: sample absorbance, the absorbance of DPPH mixed with sample

The liner curve was obtained by plotting inhibitor percentage of radical versus concentrations of compounds. 


\section{RESULTS AND DISCUSSION}

\section{Spectroscopy identification:}

The monocarbonyl curcuminoids (MCCs) (1, and 2) prepared according to (Scheme1). The proposed structure has confirmed by using spectroscopic techniques such as FTIR, Mass spectrometry, ${ }^{1} \mathrm{H}$ and ${ }^{13} \mathrm{C}$ NMR spectroscopy as well as the elemental analysis.

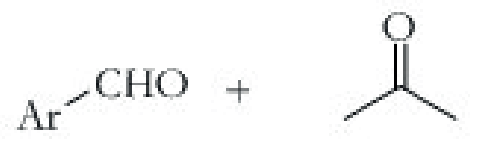

Acetone

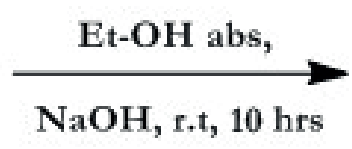

$\mathrm{NaOH}, \mathrm{r.t}, 10 \mathrm{hrs}$<smiles></smiles>

1,2<smiles>Cc1ccc2c(c1)OCO2</smiles>

\section{Scheme 1Preparation compound (MCCs).}

The (MCCs) prepared according to Claisen-Schmidt condensation reaction between acetone and, aromatic aldehyde, (scheme 2) represents the suggested preposed reaction mechanism.

(1)
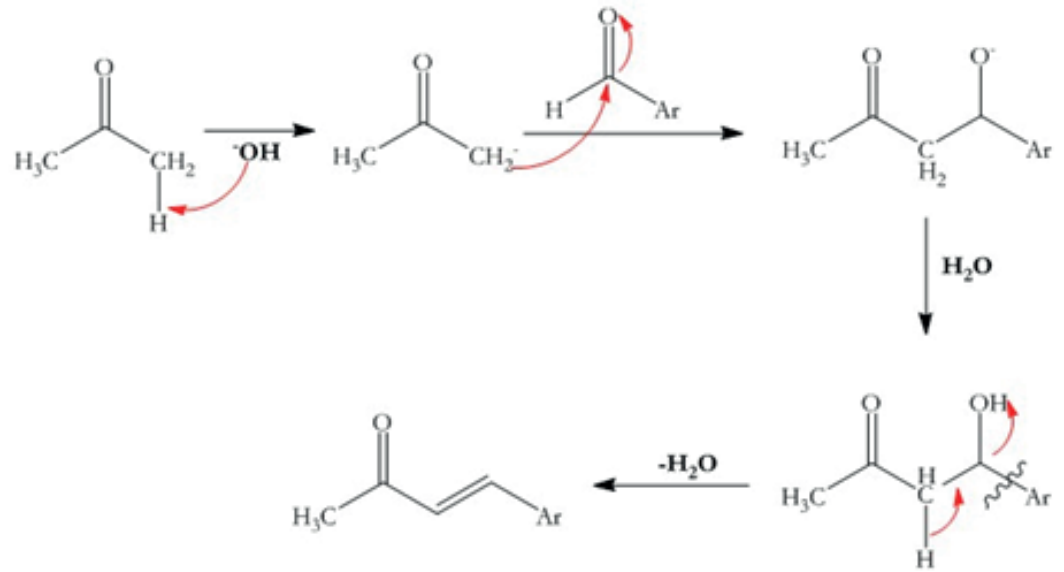

(2)
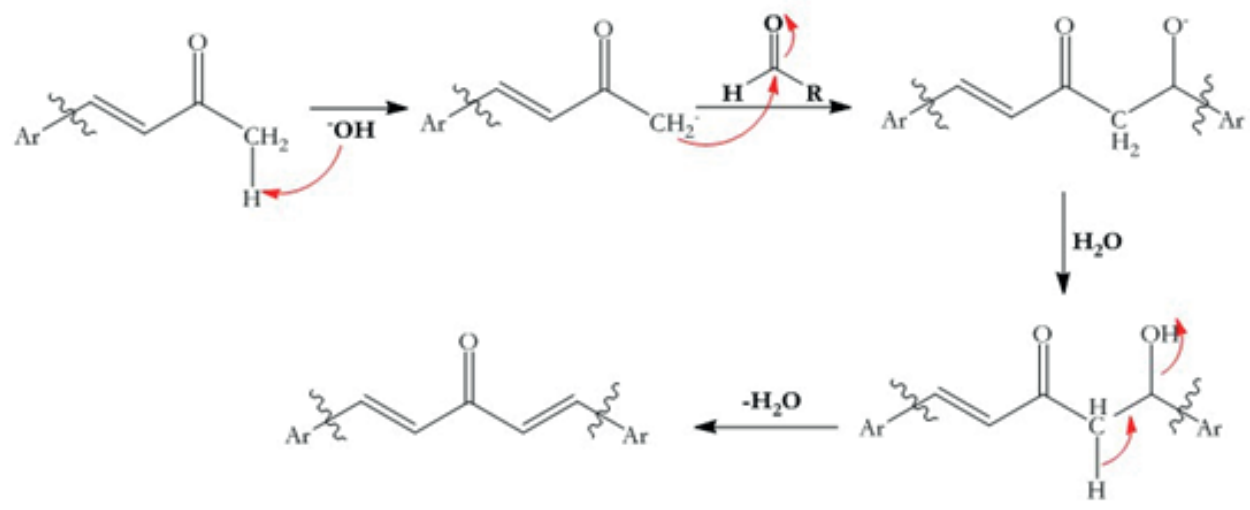

Scheme 2 Reaction mechanism of (MCCs).

\section{Innovaciencia}


The IR spectra of the prepared compounds exhibit all bands of functionalgroups. The spectra of compound (1, and 2 ) have shown stretching vibration bands at $v(3014,3016) \mathrm{cm}^{-1}$, and $v(2912,2916)$ $\mathrm{cm}^{-1}$ attributed to $\mathrm{C}-\mathrm{H}$ aliphatic, and $\mathrm{C}-\mathrm{H}$ aromatic, respectively. The Stretching vibration band appeared at $v(1643,1643.35) \mathrm{cm}^{-1}$ attributedto ketone group as well as band of $C=C$ group at $v(1598,1603) \mathrm{cm}^{-1}$. The ${ }^{1} \mathrm{HNMR}$ spectra analysis for (MCCs) at room temperature in DMSO- $\mathrm{d}_{6}$ confirmed the proposed structure. Thespectrum of compound (1) has shown singlet signal for $\mathrm{CH}_{2}-\mathrm{O}$ at $\delta(6.10)$ ppm, doublet signals of vinylic proton at $\delta(7.0$, and 7.71$) \mathrm{ppm}$ and signals at $\delta(7.19,7.26$, and 7.45$) \mathrm{ppm}$ which attributed to $\mathrm{CH}-\mathrm{C}$ aromatic. The ${ }^{13} \mathrm{CNMR}$ spectra showedsignal at $\delta$ (102) ppm,and $\delta$ (188) ppm assigned to $\mathrm{CH}_{2}-\mathrm{O}$ and ketone groups, respectively. The pyrazole derivatives of (MCCs) was synthesized from the reaction curcuminoids with hydrazine and their derivatives according to (scheme 3 ).
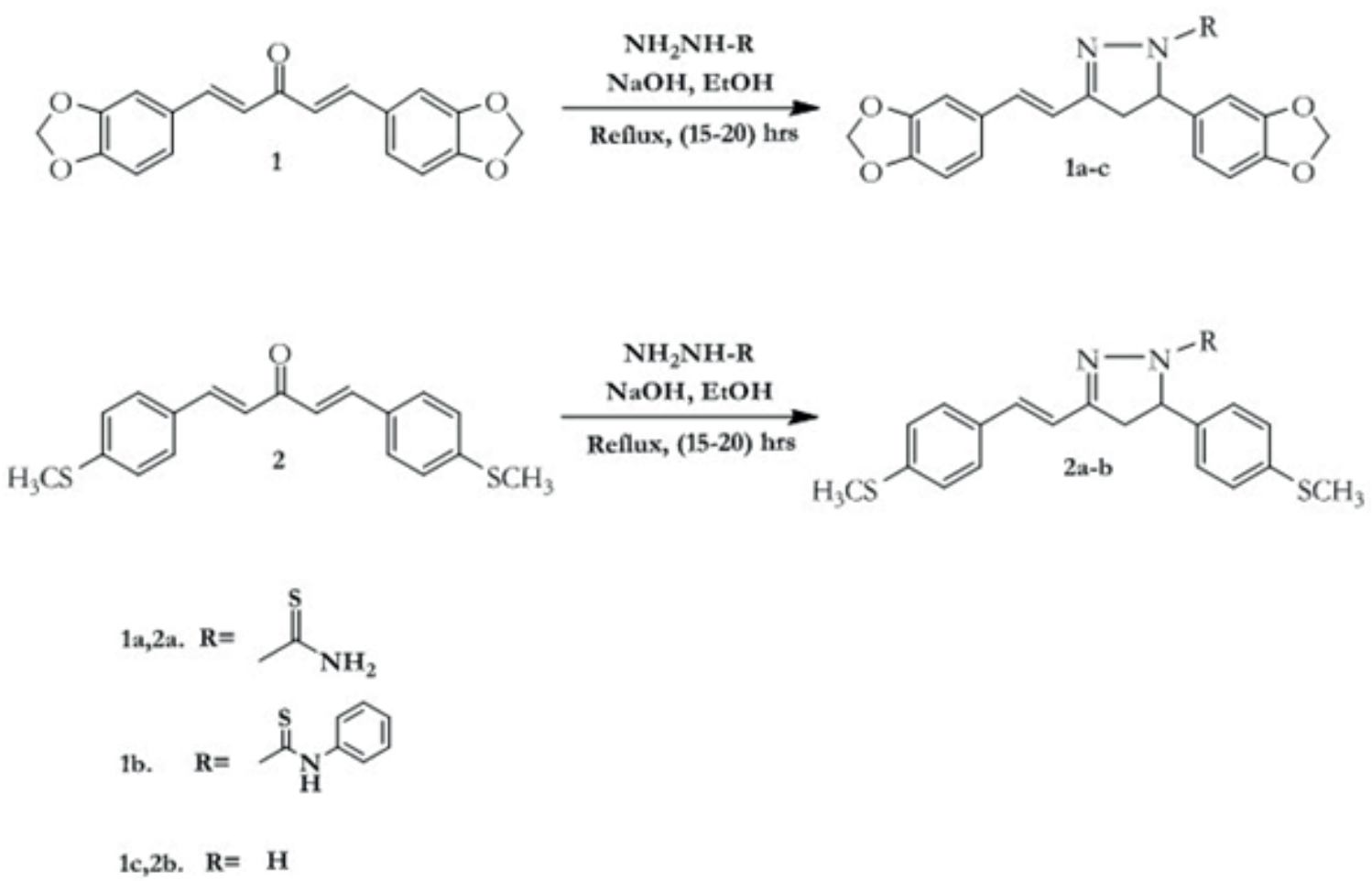

\section{Scheme 3 Preparation pyrazols of (MCCs).}

The IR spectra of pyrazole compounds show a new band at $\mathrm{v}) 1620-1627\left(\mathrm{~cm}^{-1}\right.$ attributed to the $\mathrm{C}=\mathrm{N}$ in pyrazol ring ${ }^{(16)}$, the bands at $v(3066-3014) \mathrm{cm}^{-1} \mathrm{re}-$ lated to C-H aromatic and at $v(1604-1598) \mathrm{cm}^{-1}$ assigned of stretching vibration of $\mathrm{C}=\mathrm{C}$ group.In addition, the band of carbonyl group disappeared inspectra of curcuminoids derivatives (pyrazoles). The ${ }^{1} \mathrm{HNMR}$ spectra analysis for pyrzoles show new signals due to the interaction between neighbor protons in pyrazole ring, two doublet of doublet signals at $\delta(2.49-2.97)$ ppm, and $\delta(3.68-4.0)$ ppm attribut- ed to $\mathrm{C}-\mathrm{CH}_{2}-\mathrm{C}$ of pyrazol ring as well as doublet of doublet signal at $\delta(5.05-5.85)$ ppm assigned of $\mathrm{CH}=\mathrm{N}$ of pyrazol ring ${ }^{(17)}$. In addition exhibitedsignals attributed to the aliphatic, aromatic, and vinylic protons. The ${ }^{13} \mathrm{CNMR}$ spectra of pyrazoles display signals of the carbon skeleton for pyrazoles. The spectra characterized signals attributed to aliphatic carbon, vinylic carbon, aromatic carbon, and $\mathrm{C}=\mathrm{N}$ of pyrazol ring. Mass spectra (EI)results showthe proposed formula. The elemental analysis was used to determine the molecular formula of the prepared 
compounds. In all cases, the differences in values of elemental percentage between measured and calculated formula are within acceptable values. Thecom- pound (3)was prepared from the reaction of compound (1a) with 2-chloro-1-(2,3,4-trihydroxyphenyl) ethan-1-one, according to (scheme 4).

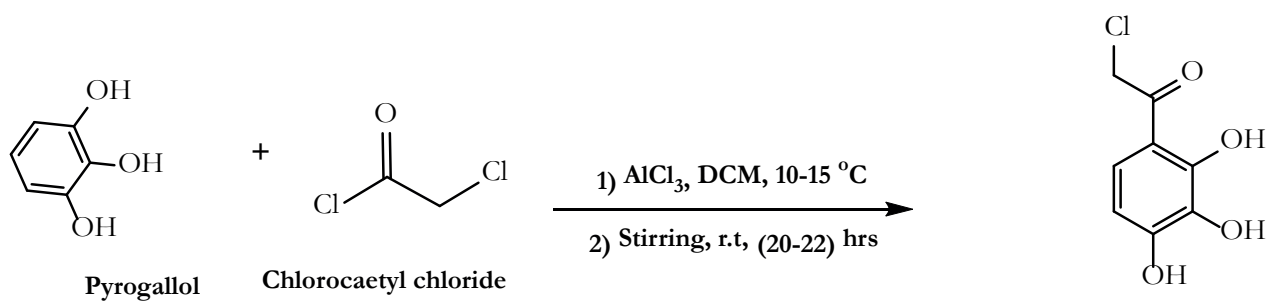

2,3,4-trihydroxyphenyl) phenecyl chloride

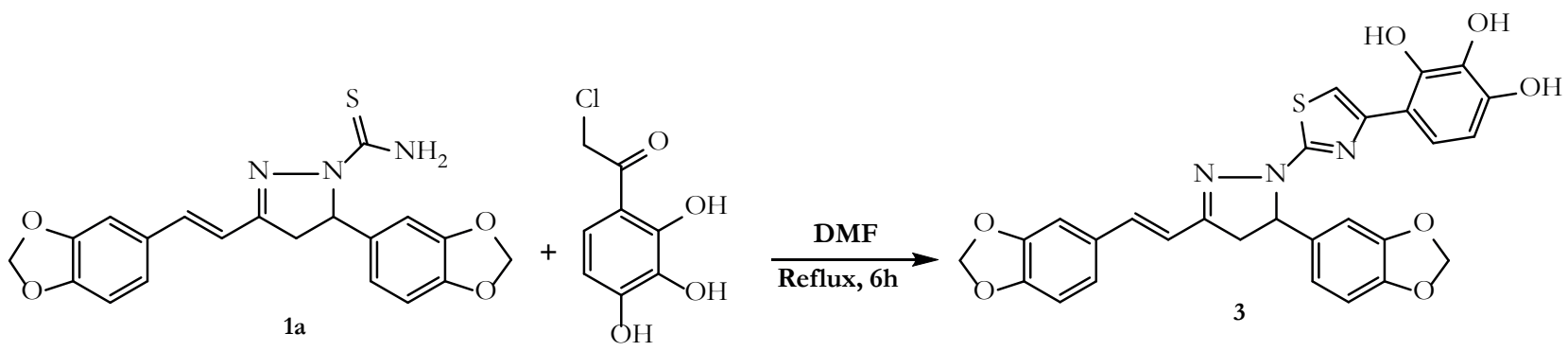

Scheme 4 preparation thiazolo thiazole of (MCCs).

The compound 2-chloro-1-(2,3,4-trihydroxyphenyl) ethan-1-one was prepared according to Friedel-Crafts reaction. The proposed structure was confirmed by using spectroscopic techniques. The IR spectrum shows strong band at $v(3390) \mathrm{cm}^{-1}$ and band at $v(1637) \mathrm{cm}^{-1}$ attributed to hydroxyl group, and carbonyl group, respectively.The ${ }^{1} \mathrm{HNMR}$ spectrum shows signal at $\delta(5.03)$ ppm, doublet signals at $\delta$ (6.44, and 7.3) ppm attributed to aromatic proton as well as three singlet signals at $\delta(8.77,10.28$, and 11.63) assigned to phenolic proton. The ${ }^{13} \mathrm{CNMR}$ spectrum shows eight signals one of them at $\delta$ (196) ppm attributed to carbonyl carbon. The Mass spectrum results improved the proposed formula. The pyrazolo thiazol derivatives characterized by spectroscopic techniques, the IR spectrum shows bands at $v(3527) \mathrm{cm}^{-1}, v(3032) \mathrm{cm}^{-1}, v(2908) \mathrm{cm}^{-1}, v(1621)$ $\mathrm{cm}^{-1}, v(1604) \mathrm{cm}^{-1}$ and $v(1087,1037) \mathrm{cm}^{-1}$ attributed to $\mathrm{C}-\mathrm{OH}, \mathrm{C}-\mathrm{H}$ aromatic, $\mathrm{C}-\mathrm{H}$ aliphatic, $\mathrm{C}=\mathrm{N}, \mathrm{C}=\mathrm{C}$, and $\mathrm{O}-\mathrm{CH}_{2}-\mathrm{O}$ groups. The ${ }^{1} \mathrm{HNMR}$ spectrum shows signals at $\delta(10.46,8.98$, and 8.06$)$ ppm attributed to phenolic proton, signals at $\delta(6.23-7.38)$ ppm attributed to olefinic and aromatic protons, as well as signal at $\delta(6.28)$ ppm assigned to $\mathrm{O}-\mathrm{CH}_{2}-\mathrm{O}$ proton and three doublet of doublet signals at $\delta(3.12,3.84$, and 5.58) ppm attributed to protons of pyrazol ring. The elemental analysis was used to determine the molecular formula of prepared compounds. In all cases, the differences in values of elemental percentage between measured and calculated formula are within the acceptable values.

\section{Antioxidant activity assay}

The in-vitro free radical inhibition activity of (MCCs) and some derivatives were analyzed by the DPPH method, the percentage of inhibition activity and the result of $\mathrm{IC}_{50}$ are gathered in (Table1), and (figure 7). The inhibition percentage activity of synthesized compounds (1, 1a, 2, 2a, and 3 ) concentration (50-200) $\mu \mathrm{mol} / \mathrm{L}$ are measured by the decreasing of DPPH absorbance at $517 \mathrm{~nm}$ with time (figures 1-6). The compounds showed lower in scavenging activity in comparison with ascorbic acid, expect the compound (3) whichshowed higherinhibition activity of $66.8 \%$ at $50 \mu \mathrm{mol} / \mathrm{L}, 78.57 \%$ at $100 \mu \mathrm{mol} / \mathrm{L}$, and $95 \%$ at $200 \mu \mathrm{mol} / \mathrm{L}$. The other compounds (1, 1a, 
2, and 2a) showed lower inhibition at $200 \mu \mathrm{mol} / \mathrm{L}$. Therefore the compound 3 showed a high inhibition activity due to the phenolic $\mathrm{OH}$ groups ${ }^{(18)}$ that able to scavenge the radicals. The scavenge of radicals ac- tivity of compounds (1, 1a, 2, 2a, and 3 ) will be in the order of: $3>2 a>1 a>2>1$. As well as half maximal inhibitory concentration $\left(\mathrm{IC}_{50}\right)$ between (17.35135.2) $\mu \mathrm{mol} / \mathrm{L}$.

Figure 2: DPPH free radical scavenging activity of compounds (1)at 50-200 $\mu \mathrm{mol} / \mathrm{L}$ concentrations showing percentage inhibition.

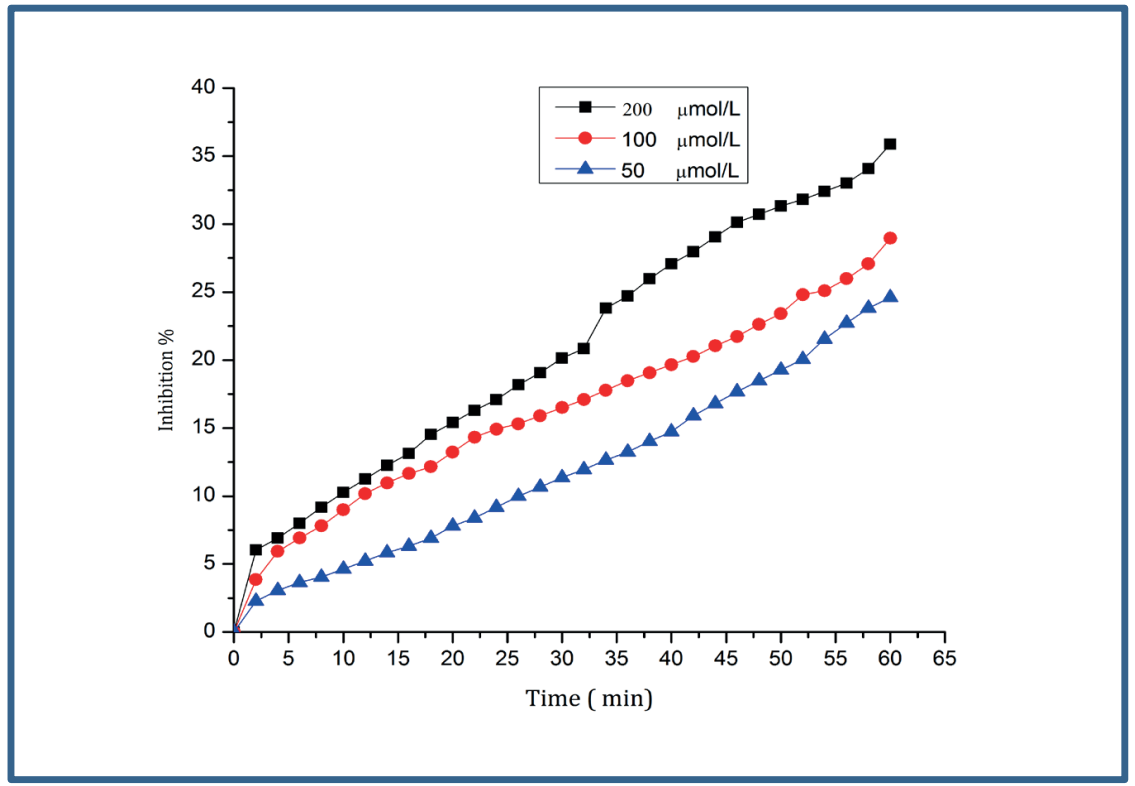

Figure 3: DPPH free radical scavenging activity of compounds (1a) at 50-200 $\mu \mathrm{mol} / \mathrm{L}$ concentrations showing percentage inhibition.

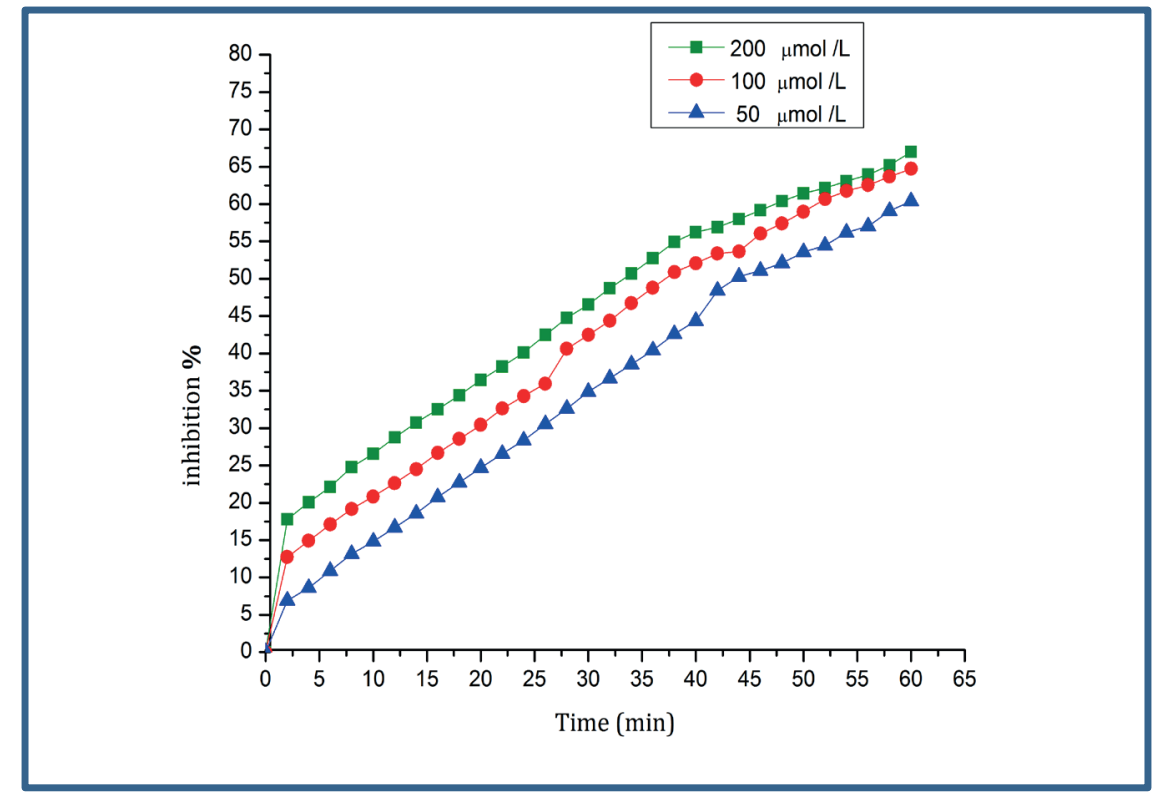


Figure 4: DPPH free radical scavenging activity of compounds (2) at $50-200 \mu \mathrm{mol} / \mathrm{L}$ concentrations showing percentage inhibition.

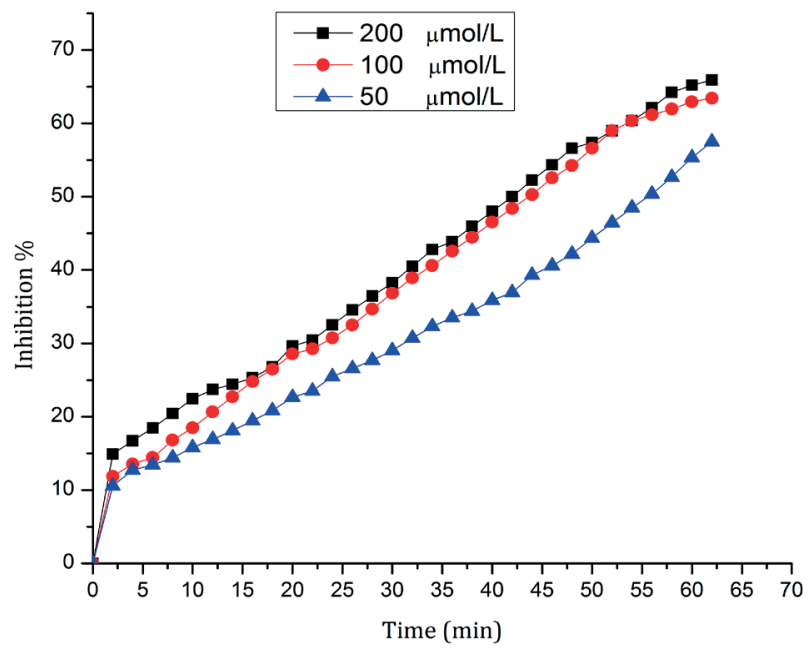

Figure 5: DPPH free radical scavenging activity of compounds (2a) at $50-200 \mu \mathrm{mol} / \mathrm{L}$ concentrations showing percentage inhibition.

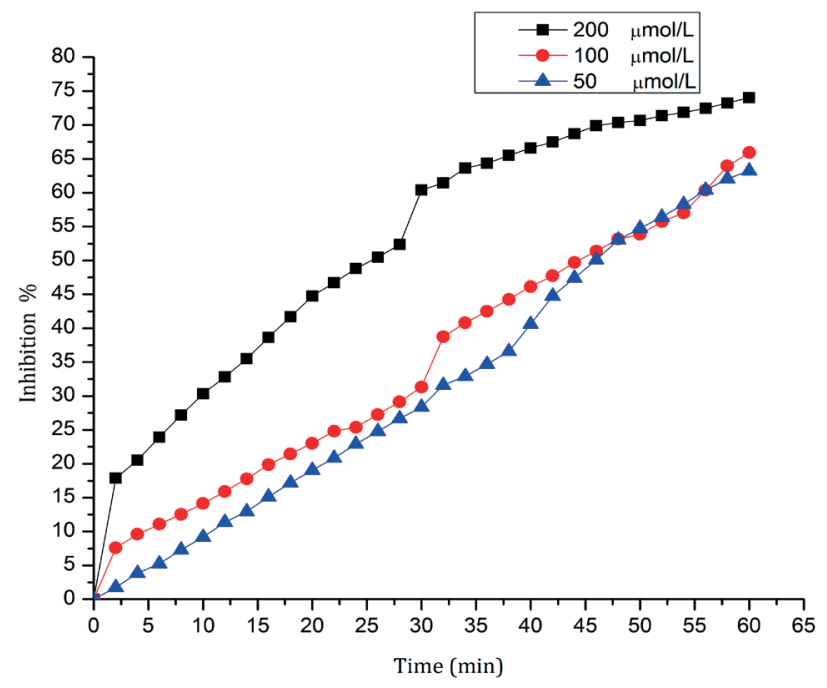


Figure 6: DPPH free radical scavenging activity of compounds (3) at 50-200 $\mu \mathrm{mol} / \mathrm{L}$ concentrations showing percentage inhibition.

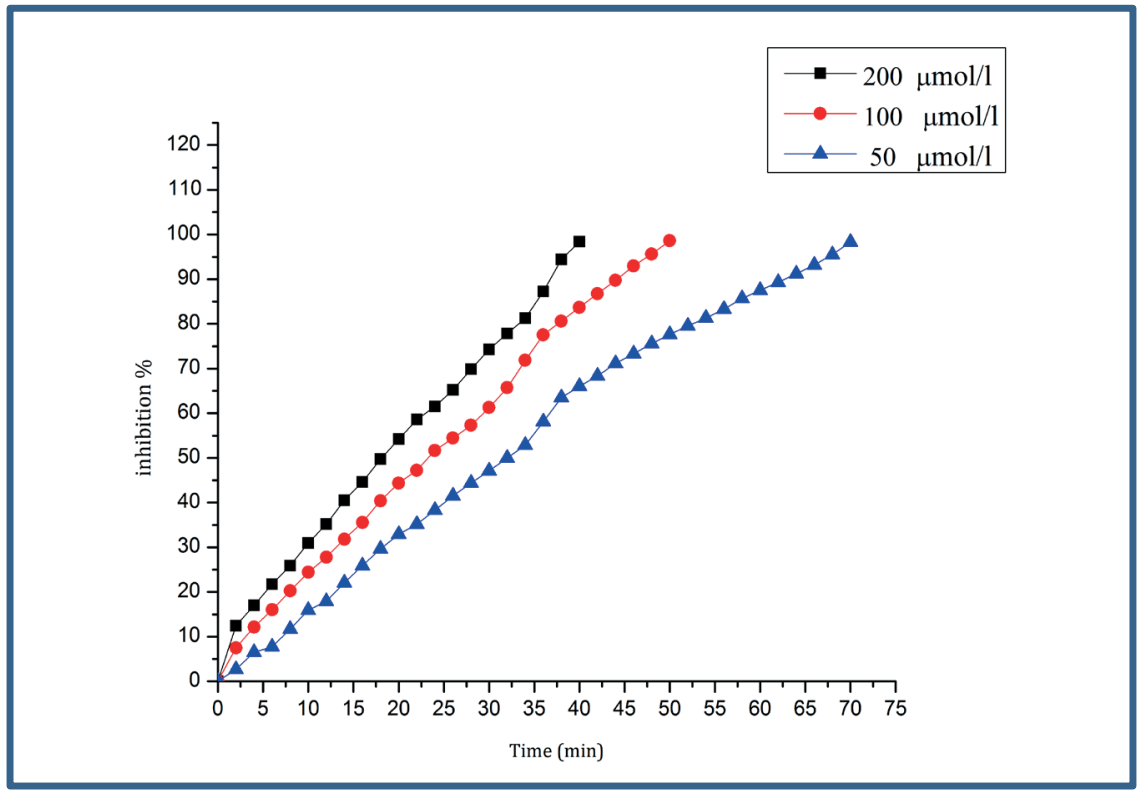

Figure 7: DPPH free radical scavenging activity of ascorbic acid at $200 \mu \mathrm{mol} / \mathrm{L}$ concentrations showing percentage inhibition.

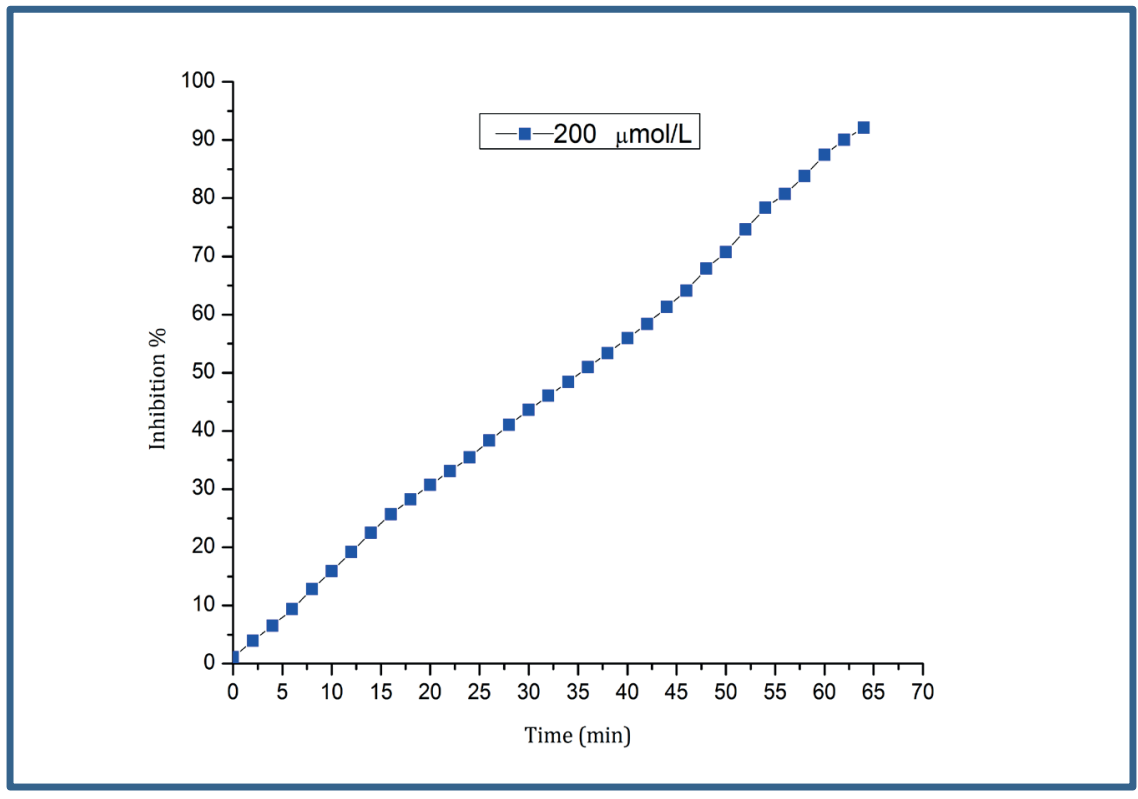


Figure 8: The percentage inhibition of DPPH free radical scavenging activity of compounds $(1,1 \mathrm{a}, 2,2 \mathrm{a}, 3$, andVit.C) at 50-200 $\mu \mathrm{mol} / \mathrm{L}$ concentrations.

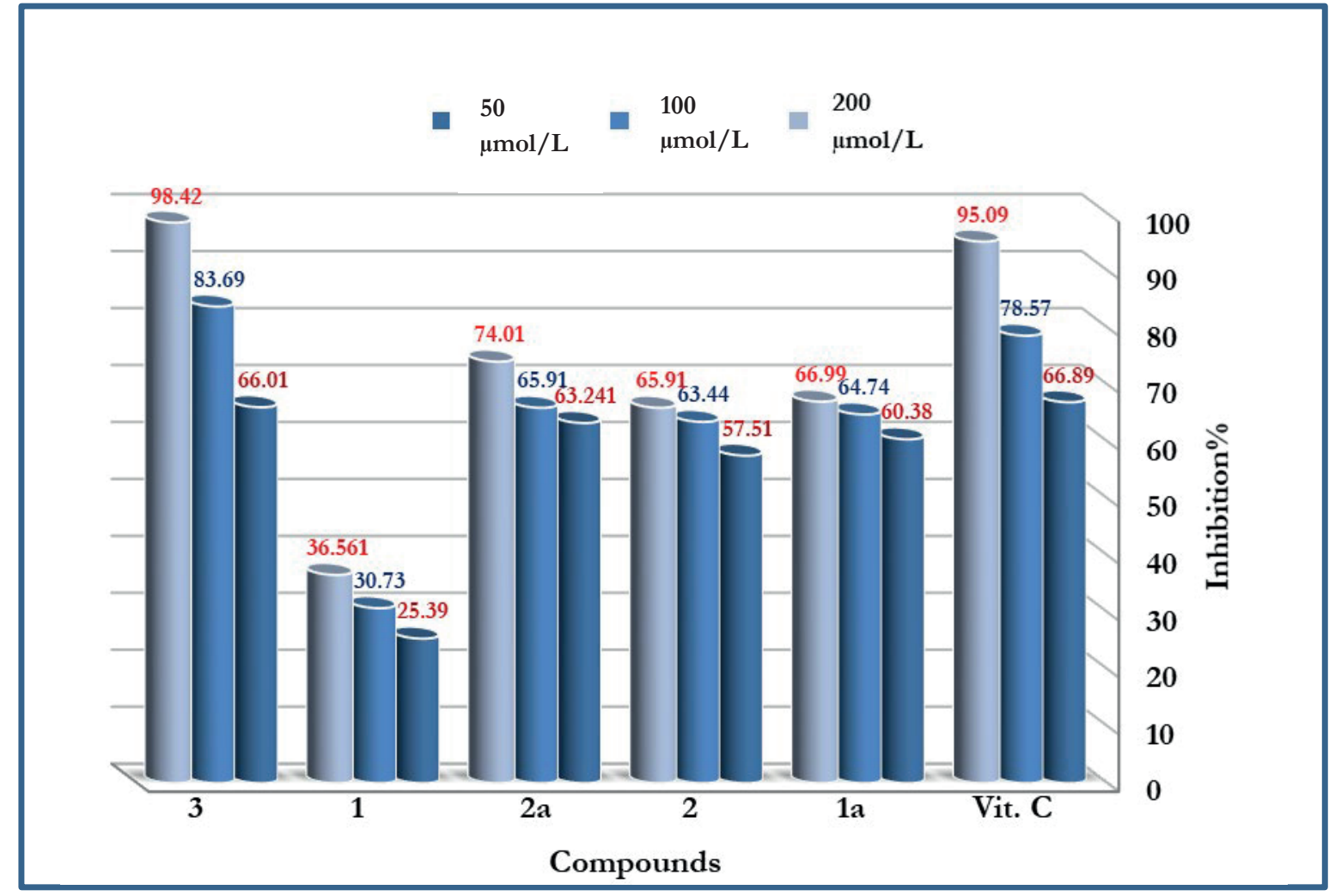

Tabla 1: In-vitro antioxidant activities of compounds (1, 1a, 2, 2a, and 3).

\begin{tabular}{|c|c|c|c|c|}
\hline \multirow{2}{*}{ Compounds } & \multicolumn{2}{|r|}{ Percentage of } & \multicolumn{2}{|l|}{ Inhibition } \\
\hline & $50 \mu \mathrm{mol} / \mathrm{L}$ & $100 \mu \mathrm{mol} / \mathrm{L}$ & $200 \mu \mathrm{mol} / \mathrm{L}$ & IC $50 \mu \mathrm{mol} / \mathrm{L}$ \\
\hline Ascorbic acid & 66.89 & 78.57 & 95.09 & 18.74 \\
\hline $1 \mathrm{a}$ & 60.38 & 64.74 & 66.99 & 60.12 \\
\hline 2 & 57.51 & 63.44 & 65.91 & 20.97 \\
\hline $2 \mathrm{a}$ & 63.241 & 65.91 & 74.01 & 31.59 \\
\hline 1 & 25.39 & 30.73 & 36.561 & 135.2 \\
\hline 3 & 66.01 & 83.69 & 98.42 & 17.35 \\
\hline
\end{tabular}

\section{CONCLUSIONS}

In this study, the monocarbonyl curcuminoids (MCCs) was synthesized according to ClaisenSchmidt condensation reaction between acetone and aromatic aldehydes, followed by synthsis of their derivatives. The IR, ${ }^{1} \mathrm{HNMR},{ }^{13} \mathrm{CNMR}$, and Mass spectra as well as elemental analysis of the studiedcompounds are considered as the essential identification. The antioxidant activity of curcuminoids were studied by using DPPH as a source of radicals. The higher activity of compounds can be attributed to present the phenolic $\mathrm{OH}$ group. $\mathrm{IC}_{50}$ value between $(17.35-135.2) \mu \mathrm{mol} / \mathrm{L}$. 


\section{REFERENCES}

1. Baldwin PR, Reeves AZ, Powell KR, Napier RJ, Swimm AI, Sun A, et al. Monocarbonyl analogs of curcumin inhibit growth of antibiotic sensitive and resistant strains of Mycobacterium tuberculosis. European Journal of Medicinal Chemistry. 2015;92:693-9.

2. Alsalim TAQ, Mzban HA, Abood EN. Synthesis and antioxidant study of new hydrazones derived from bisdemethoxycurcumin pyrazole. European Journal of Chemistry. 2017;8(4):344-8.

3. Zhu H, Xu T, Qiu C, Wu B, Zhang Y, Chen L, et al. Synthesis and optimization of novel allylated mono-carbonyl analogs of curcumin (MACs) act as potent anti-inflammatory agents against LPS-induced acute lung injury (ALI) in rats. European Journal of Medicinal Chemistry. 2016;121:18193.

4. Lozada-Garcia MC, Enriquez RG, Ramirez-Apan TO, Nieto-Camacho A, Palacios-Espinosa JF, Custodio-Galvan Z, et al. Synthesis of Curcuminoids and Evaluation of Their Cytotoxic and Antioxidant Properties. Molecules. 2017;22(4).

5. Gyuris M, Hackler Jr. L, Nagy LI, Alföldi R, Rédei E, Marton A, et al. Mannich Curcuminoids as Potent Anticancer Agents. Archiv der Pharmazie. 2017;350(7):e1700005.

6. Martins CVB, da Silva DL, Neres ATM, Magalhães TFF, Watanabe GA, Modolo LV, et al. Curcumin as a promising antifungal of clinical interest. Journal of Antimicrobial Chemotherapy. 2008;63(2):337-9.

7. NITA CHAINANI-WU DMD, M.P.H., M.S. Safety and Anti-Inflammatory Activity of Curcumin: A Component of Tumeric (Curcuma longa). THE JOURNAL OF ALTERNATIVE AND COMPLEMENTARY MEDICINE. 2003;9(1):8.

8. Kali A, Bhuvaneshwar D, Charles PMV, Seetha KS. Antibacterial synergy of curcumin with antibiotics against biofilm producing clinical bacterial isolates. Journal of basic and clinical pharmacy. 2016;7(3):93-6.

9. Mathew D, Hsu W-L. Antiviral potential of curcumin. Journal of Functional Foods. 2018;40:6929.
10. Sharma S, Gupta MK, Saxena AK, Bedi PMS. Triazole linked mono carbonyl curcumin-isatin bifunctional hybrids as novel anti tubulin agents: Design, synthesis, biological evaluation and molecular modeling studies. Bioorganic \& Medicinal Chemistry. 2015;23(22):7165-80.

11. Liang B, Liu Z, Cao Y, Zhu C, Zuo Y, Huang L, et al. MC37, a new mono-carbonyl curcumin analog, induces $\mathrm{G} 2 / \mathrm{M}$ cell cycle arrest and mitochondria-mediated apoptosis in human colorectal cancer cells. European Journal of Pharmacology. 2017;796:139-48.

12. Blois M.S. Antioxidant determinations by the use of a stable free radical. Nature.1958; 181:11991200

13. Benmehdi H, Behilil A, Memmou F, Amrouche A. Free radical scavenging activity, kinetic behavior and phytochemical constituents of Aristolochia clematitis L. roots. Arabian Journal of Chemistry, 2017; 10: 1402-1408

14. Anand P, Thomas SG, Kunnumakkara AB, Sundaram C, Harikumar KB, Sung B, et al. Biological activities of curcumin and its analogues (Congeners) made by man and Mother Nature. Biochemical Pharmacology. 2008;76(11):1590-611.

15. Bayomi SM, El-Kashef HA, El-Ashmawy MB, Nasr MNA, El-Sherbeny MA, Badria FA, et al. Synthesis and biological evaluation of new curcumin derivatives as antioxidant and antitumor agents. Medicinal Chemistry Research. 2012;22(3):1147-62.

16. Ausra Voskiene aVM, a and Gema Mikulskiene. Synthesis and structural characterization of products condensation 4-carboxy-1-(4-styrylcarbonylphenyl)-2-pyrrolidinones with hydrazines. ARKIVOC 2007;(xv):303-14.

17.Emam DR, Alhajoj AM, Elattar KM, Kheder NA, Fadda AA. Synthesis and Evaluation of Curcuminoid Analogues as Antioxidant and Antibacterial Agents. Molecules. 2017;22(6).

18. Bade TS, Ebrahimi HP, Alsalim TA, Titinchi SJJ, Abbo HS, Bolandnazar Z, et al. A novel series of 1, 4-Dihydropyridine (DHP) derivatives bearing thiazolidin-4-one: From synthesis to structure. Journal of Molecular Structure. 2017;1138:13648. 